\title{
Massive hemorrhage after percutaneous kidney biopsy caused by renal artery malformation: a case report and literature review
}

\author{
Dong Liang ${ }^{1 \dagger}$, Hui Zhang ${ }^{1 \dagger}$, Min Yang ${ }^{1}$, Hong Ji ${ }^{2}$, Gang Chen ${ }^{3}$, Ning Yu ${ }^{2}$ and Xiaomin Zhang ${ }^{1 *}$
}

\begin{abstract}
Background: Accessory renal artery (ARA) is the most common site for anatomical variation of renal supply artery. Rare studies reported interventional embolization for the management of massive hemorrhage caused by ARA injury after percutaneous kidney biopsy (PKB).

Case presentation: We describe a 35-year-old man who developed massive hemorrhage after PKB leading to shock. Digital subtraction angiography (DSA) showed hemorrhage in the ARA at the inferior pole of the right kidney and hemostasis was noticed after renal artery embolization.

Conclusions: We proposed that much attention should be paid to the presence of ARA before PKB. In addition, digital subtraction angiography combined with superselective embolization is the best choice for the treatment of renal artery injury.
\end{abstract}

Keywords: Kidney, Biopsy, Accessory renal artery, Hemorrhage, Embolization

\section{Background}

Percutaneous kidney biopsy (PKB) is the primary diagnostic tool for the determination of pathological type and severity of renal disease. In clinical settings, PKB has been well accepted by the majority of patients as it is mini-invasive. However, many patients present renal injury, hematuria, perirenal hematomas, arteriovenous fistulas and infection afterwards. Rare cases show lifethreatening massive hemorrhage.

Accessory renal artery (ARA), a functional terminal vessel entering the kidney directly or via the renal hilum, shows the highest incidence of anatomic variation in the

*Correspondence: zhangxiaomin7926@126.com

${ }^{\dagger}$ Dong Liang and Hui Zhang equally contributed to this work

${ }^{1}$ Department of Nephrology, Binzhou Medical University Hospital, No.

661 Huanghe Second Road, Binzhou 256603, Shangdong, P.R. China

Full list of author information is available at the end of the article renal arteries. The presence of ARA can significantly increase vascular and urologic complications during renal surgery $[1,2]$. To our best knowledge, rare studies reported massive hemorrhage caused by ARA injury during or after renal biopsy. In this study, we presented a case underwent $\mathrm{PKB}$ with massive renal hemorrhage due to ARA injury.

\section{Case presentation}

A 35-year-old man referred to our department due to urinary abnormalities in January 2012. He showed no fever, joint and muscle pain, rash, diarrhea, lymphadenopathy, malar rash, oral ulcer, lumbar pain, photosensitivity or arthralgia, headache, chest tightness, suffocation, or palpitation. The heart rate was 82 beats per minute, and respiratory rate was 20 breaths per minute. The blood pressure was $154 / 95 \mathrm{mmHg}$. The laboratory findings were as follows: white blood cells (WBCs), $5.22 \times 10^{9} / \mathrm{L}$; 
hemoglobin $(\mathrm{Hb}) 125 \mathrm{~g} / \mathrm{L}$, red blood cells (RBCs), $4.08 \times 10^{12} / \mathrm{L}$; platelet $2.96 \times 10^{11} / \mathrm{L}$; albumin, $59.7 \mathrm{~g} / \mathrm{L}$; blood urea nitrogen, $5.27 \mathrm{mmol} / \mathrm{L} ; \mathrm{C} 4,18.7 \mathrm{mg} / \mathrm{dL}$; C3, $118 \mathrm{mg} / \mathrm{dL}$; and creatinine, $79.6 \mu \mathrm{mol} / \mathrm{L}$. The hepatitis b surface antigen, anti-hepatitis B e antibody and antihepatitis B core antibody were positive. The serum HBV DNA level was $1.28 \times 10^{3} \mathrm{IU} / \mathrm{mL}$. There was urine blood $(++)$ and protein $(++)$. The urine total protein was $0.74 \mathrm{~g} / 24 \mathrm{~h}$. There were negative findings in the tests of anti-nuclear antibody (ANA), antineutrophil cytoplasmic antibodies (ANCA), anti-DNA antibodies, anti-myeloperoxidase (MPO) and proteinase 3 (PR3) antibodies, antiglomerular basement membrane (anti-GBM) antibodies and anti-Streptolysin O. To identify the cause of urinary occult blood and the existence of hepatitis B associated glomerulonephritis, the patient was recommended to receive renal biopsy.

Tru-cut puncture needle (16-gauge) was inserted in the lower pole of the right kidney for 3 times, and the puncture point was pressed for at least $5 \mathrm{~min}$ after renal biopsy. Afterwards, cefthiamidine ( $2.0 \mathrm{~g})$ was given via intravenous drip to prevent infection. The patient presented no obvious discomfort during and after the biopsy. About 4 days later, he showed sudden shock after strenuous exercise with a systolic blood pressure of $80 \mathrm{mmHg}$ accompanied by gross hematuria. Then the patient was carefully checked. The patient was required to rest in bed, and was immediately given hemostasis, continuous catheterization, and fluid replacement therapy. The catheterization led to a dark red color with blood clots $(600 \mathrm{~mL})$. Meanwhile, the ultrasound of the urinary system showed no obvious changes in the size and shape of the right kidney, and the collection system was separated by $1.1 \mathrm{~cm}$. The bladder cavity had a low echo, suggesting a blood clot. Combined with the renal biopsy, renal hemorrhage was considered. After 2 days of conservative treatment, the patient showed dizziness, chest tightness with throbbing pain in the right waist, decrease of blood pressure to $59 / 36 \mathrm{mmHg}$. The $\mathrm{Hb}$ was $82 \mathrm{~g} / \mathrm{L}$. Considering the bleeding and rapid decrease of hemoglobin, the patients received infusion of concentrated red cell. Ultrasonography showed that a $2.9 \mathrm{~cm} \times 2.2 \mathrm{~cm} \times 2.0 \mathrm{~cm}$ low echo considering the blood clot in the right renal pelvis, and a low echo $(14.2 \mathrm{~cm} \times 8.0 \mathrm{~cm} \times 9.1 \mathrm{~cm})$ was considered blood clots in the bladder. After continuous catheterization, there was still light red fluid with waist pain. ECG monitoring showed a blood pressure of $110 / 65 \mathrm{mmHg}$, heart rate of $85 \mathrm{bpm}$ and $\mathrm{Hb}$ of $54 \mathrm{~g} / \mathrm{L}$. In the presence of active bleeding, he was transmitted immediately to the Intensive Care Unit (ICU), where interventional embolization treatment was given. There was hemorrhage in the ARA at the inferior pole of the right kidney (Fig. 1). The hemorrhage was terminated after embolization (Fig. 2).
Renal biopsy indicated IgA nephrology. It was found that the punctured kidney tissue included cortical tissue, cortical medulla junction tissue and medulla tissue, of which about $10 \%$ of the medulla tissue. Based on the Oxford classification for the IgA nephropathy [3], the score was M1E0S1T1C0. Finally, the patient was discharged with no sequela. In the 1-year follow-up, there was no gross hematuria or signs of renal insufficiency.

\section{Discussion}

Renal pathology is critical for the establishing of treatment plan and evaluation of prognosis among patients with renal disease. To date, PKB is considered to be an irreplaceable tool for the diagnosis, prognosis, and treatment of a variety of renal diseases. Despite the presence of a variety of new techniques, hemorrhage is inevitable after PKB [4-6]. Hemorrhage is considered the most common postoperative complication. The most significant complication of PKB is vascular damages with subsequent hemorrhage [7]. To date, there are many cases with injuries in lumbar artery and extrarenal artery, including mesenteric artery, intercostal artery and abdominal aorta. However, few reports focused on the hemorrhage caused by ARA injury after renal biopsy. A comprehensive literature research was conducted to the PubMed database and EMbase using the following key words: accessory renal artery; hemorrhage. Only three cases including our case were found $[8,9]$ (Table 1 ).

Arteries entering the kidney are divided into main and the ARA. Compared with the renal artery, the ARA started from the starting point showed smaller internal diameter than that of the renal artery. The path was longer, and its perfusion pressure was low. The blood flow resistance was high, and it was more prone to stenosis and bleeding. The incidence of ARA in Chinese is $14.5 \%$ [10], which varies in different countries, populations, genders, left and right sides. According to the previous studies [11, 12], ARA can originate from various arteries, including abdominal aorta, aortic and renal artery, external ilium artery, lumbar artery, as well as spleen artery. The most common variation of the renal artery was originated from the abdominal aorta, and the inferior renal artery was the most common type of variation. The lateral visceral artery of the embryo did not completely disappear during the development of the human body, which formed the ARA. This represented the traces of the blood supply of the kidney and embryo. The ARA was complex in origin, course, and position of entering the renal hilum, which increased the complexity of renal vascular anatomy and the difficulty of related surgical operation. In addition, the existence of the ARA was potentially associated with renovascular hypertension [13] and hydronephrosis [14]. 

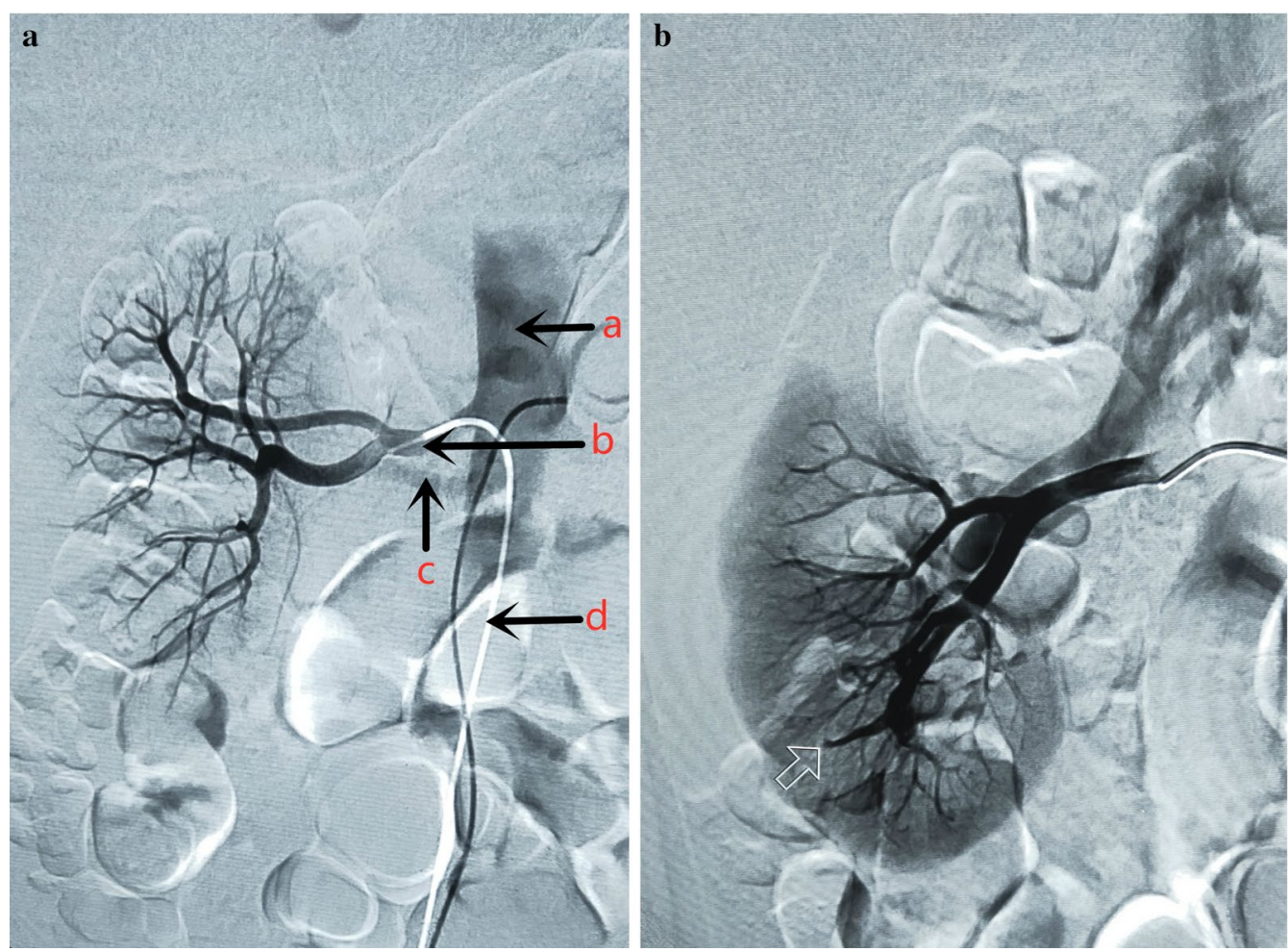

Fig. 1 Image of right kidney by DSA. a Angiography from main renal artery. (a) Abdominal aorta; (b) Right renal artery; (c) accessory renal artery (ARA); (d) Interventional catheter. b Angiography from ARA. The arrow pointed to the site of arterial injury caused by the biopsy needle

For the patients with a small dimension of main renal artery by ultrasonography, there may be an ARA [15]. There was a certain diagnostic rate for ARA by ultrasonography and a high rate of misdiagnosis and missed diagnosis due to obesity or bowel gas. However, ultrasonography could be used as a preliminary screening test for ARA with features of convenient operation, repeatability and non-invasiveness. Unfortunately, the ARA can be easily misdiagnosed as renal artery stenosis solely based on the size of the diameter. As a non-invasive examination, CTA can clearly show the ARA with a diameter of more than $0.5 \mathrm{~mm}$. In addition to clearly displaying the diameter of the renal artery, it can also show the number and shape of the renal artery, which can be utilized as a standard for evaluating the preoperative anatomical structure of the renal artery [16]. Digital subtraction angiography (DSA) is the gold standard for the diagnosis of renal vascular malformations. It is superior in displaying the branches of small arteries and evaluating the capacity of multiple supply vessels. In clinical practice, the non-invasive imaging methods are more likely to be accepted by patients, such as computed tomography angiography (CTA), and color Doppler ultrasound. Therefore, ultrasonography is suitable for primary screening and iodine allergy, renal failure,

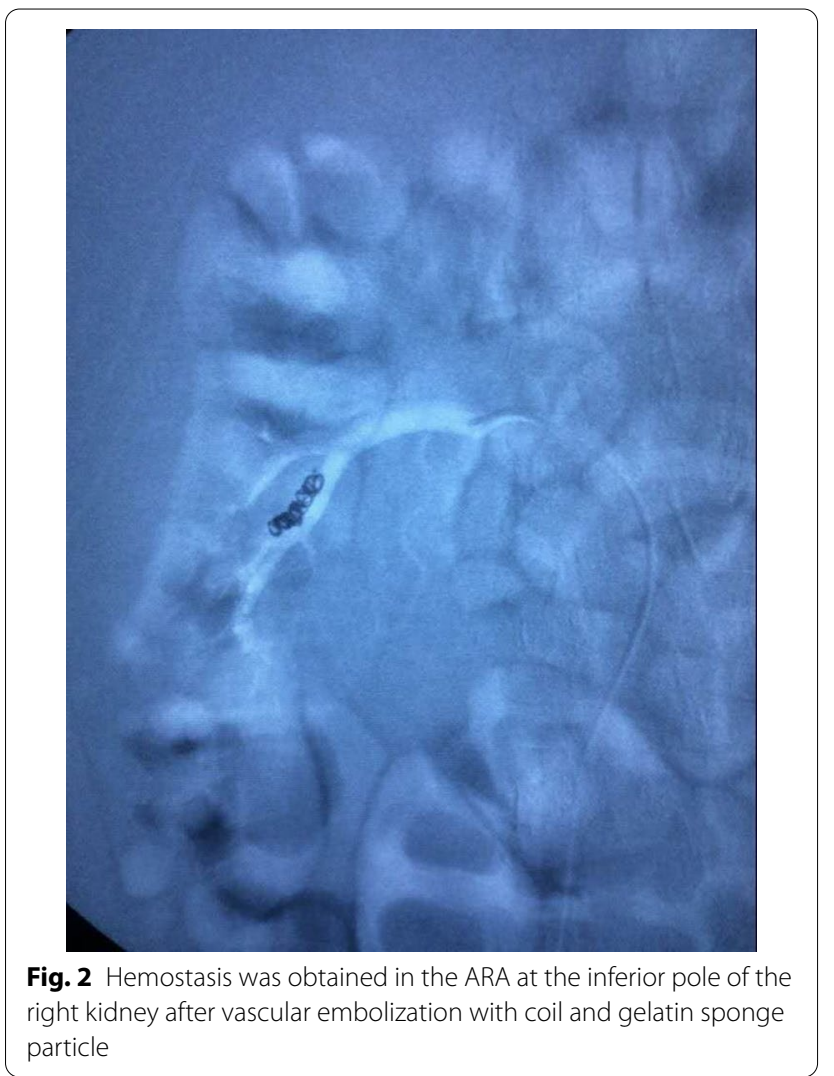


and pregnancy. Taken together, CTA can be used for routine examination, while DSA can be used for the final diagnosis.

Superselective renal artery embolization was regarded as a safe and effective treatment strategy for hemorrhage after PKB. For the patients with no signs of hemorrhage after renal arteriography, lumbar or iliolumbar arteriography is necessary [17]. Some patients may present complications after renal artery embolism, including post-embolism syndromes, infection and renal insufficiency [18], despite a lower incidence of renal artery embolism. The post-embolism syndrome is characterized by fever and lower-back pain. After symptomatic treatment, the complications after embolization were attenuated without special treatment. In our case, he showed no significant complications after embolization in the follow-up (Table 2).
In this case, we realized that iatrogenic renal hemorrhage should be considered when there were a serious hematuria and shock symptoms after renal biopsy, in which ARA injury was one of the causes. For the treatment of iatrogenic renal hemorrhage, routine medical conservative treatment was the first choice and then interventional therapy or surgical treatment must be considered. Medical treatment included absolute bed rest, ECG monitoring, recording the color and total amount of drainage, intravenous application of hemostatic drugs, continuous catheterization, as well as fluid replacement. At the same time, blood routine examination should be regularly reviewed, blood coagulation function should be monitored, and plasma or concentrated red blood cells should be infused if necessary. While ensuring the body temperature, correct the possible acidosis and maintain the stability of the internal environment. Patients with

Table 1 Cases with hemorrhage after PKB caused by accessory renal artery injury

\begin{tabular}{|c|c|c|c|c|c|c|c|c|c|}
\hline \multirow{2}{*}{$\begin{array}{l}\text { Author } \\
\text { (year) }\end{array}$} & \multicolumn{3}{|c|}{ Basic conditions } & \multirow{2}{*}{$\begin{array}{l}\text { Initial clinical } \\
\text { diagnosis }\end{array}$} & \multirow{2}{*}{$\begin{array}{l}\text { Involved } \\
\text { artery }\end{array}$} & \multirow{2}{*}{$\begin{array}{l}\text { Origin } \\
\text { of the injured } \\
\text { artery }\end{array}$} & \multirow{2}{*}{$\begin{array}{l}\text { Pathological } \\
\text { diagnosis }\end{array}$} & \multirow[t]{2}{*}{ Treatment } & \multirow[t]{2}{*}{ Prognosis } \\
\hline & Age, years & Gender & $\begin{array}{l}\text { Basic } \\
\text { diseases }\end{array}$ & & & & & & \\
\hline $\begin{array}{l}\text { Harada et al. } \\
\text { [8] }\end{array}$ & Male & 24 & Obesity & $\begin{array}{l}\text { Obesity- } \\
\text { related } \\
\text { nephropa- } \\
\text { thy }\end{array}$ & $\begin{array}{l}\text { Aberrant renal } \\
\text { artery at the } \\
\text { lower pole } \\
\text { of the right } \\
\text { kidney }\end{array}$ & Aorta & $\begin{array}{l}\text { Benign } \\
\text { nephroscle- } \\
\text { rosis with } \\
\text { second- } \\
\text { ary focal } \\
\text { segmental } \\
\text { glomerulo- } \\
\text { sclerosis }\end{array}$ & $\begin{array}{l}\text { Transarterial } \\
\text { emboliza- } \\
\text { tion }\end{array}$ & $\begin{array}{l}\text { Hemosta- } \\
\text { sis and } \\
\text { complete } \\
\text { remission } \\
\text { of pro- } \\
\text { teinuria }\end{array}$ \\
\hline $\begin{array}{l}\text { Zhang et al. } \\
\text { [9] }\end{array}$ & Male & 67 & Hypertension & $\begin{array}{l}\text { Nephrotic } \\
\text { syndrome }\end{array}$ & $\begin{array}{l}\text { Aberrant renal } \\
\text { artery at the } \\
\text { lower pole } \\
\text { of the right } \\
\text { kidney }\end{array}$ & Not available & $\begin{array}{l}\text { AL-type renal } \\
\text { amyloidosis }\end{array}$ & $\begin{array}{l}\text { Renal } \\
\text { arteriog- } \\
\text { raphy and } \\
\text { vascular } \\
\text { emboliza- } \\
\text { tion }\end{array}$ & Hemostasis \\
\hline This case & Male & 35 & $\begin{array}{l}\text { HBsAg, Anti- } \\
\text { HBe, and } \\
\text { Anti-HBc } \\
\text { positive }\end{array}$ & $\begin{array}{l}\text { Hepatitis B } \\
\text { associated } \\
\text { glomeru- } \\
\text { lonephritis, } \\
\text { suspected }\end{array}$ & $\begin{array}{l}\text { Aberrant renal } \\
\text { artery at the } \\
\text { lower pole } \\
\text { of the right } \\
\text { kidney }\end{array}$ & Aorta & $\begin{array}{l}\text { IgA Nephrol- } \\
\text { ogy }\end{array}$ & $\begin{array}{l}\text { Superselec- } \\
\text { tive renal } \\
\text { artery } \\
\text { emboliza- } \\
\text { tion }\end{array}$ & Hemostasis \\
\hline
\end{tabular}

Table 2 Patient blood pressure and related laboratory data

\begin{tabular}{|c|c|c|c|}
\hline & On admission & Before operation & 3 days after operation \\
\hline Blood pressure (BP) & $154 / 95 \mathrm{mmHg}$ & $110 / 65 \mathrm{mmHg}$ & $122 / 73 \mathrm{mmHg}$ \\
\hline Heart rate $(H R)$ & 82 bpm & 87 bpm & 80 bpm \\
\hline Hemoglobin (Hb) (110 g/L-160 g/L) & $125 \mathrm{~g} / \mathrm{L}$ & $54 \mathrm{~g} / \mathrm{L}$ & $78 \mathrm{~g} / \mathrm{L}$ \\
\hline Platelet $(\mathrm{PLT})\left(1.0 \times 10^{11} / \mathrm{L}-3.0 \times 10^{11} / \mathrm{L}\right)$ & $2.96 \times 10^{11} / \mathrm{L}$ & $2.6 \times 10^{11} / \mathrm{L}$ & $3.18 \times 10^{11} / \mathrm{L}$ \\
\hline Prothrombin time (PT) (11S-15S) & 14.05 & $13.6 \mathrm{~S}$ & - \\
\hline Activated partial thromboplastin time (APTT) (28S-34S) & 38.05 & $34.6 S$ & - \\
\hline International normalized ratio (INR) (0.8-1.5) & 1.09 & 1.01 & - \\
\hline Blood urea nitrogen (BUN) (3.9 mmol/L-7.1 mmol/L) & $5.27 \mathrm{mmol} / \mathrm{L}$ & $4.13 \mathrm{mmol} / \mathrm{L}$ & $5.34 \mathrm{mmol} / \mathrm{L}$ \\
\hline Serum creatinine concentration $(\mathrm{s} C r)(0 \mu \mathrm{mol} / \mathrm{L}-132 \mu \mathrm{mol} / \mathrm{L})$ & $79.6 \mu \mathrm{mol} / \mathrm{L}$ & $101.3 \mu \mathrm{mol} / \mathrm{L}$ & $74.1 \mu \mathrm{mol} / \mathrm{L}$ \\
\hline
\end{tabular}

- Means not detected 
no responses to conservative treatment should be treated with interventional or surgical treatment in time.

\section{Conclusions}

The presence of ARA may be one of the factors that increase the risk of bleeding in renal biopsy. For the patients underwent $\mathrm{PKB}$, the color Doppler ultrasonography should be perfected before the operation. In addition, attention should be paid to the possibility of abnormal renal arterial hemorrhage. Suspicion for ARA injury with active hemorrhage is a definite indication for CTA or DSA. Moreover, superselective renal artery embolization may be the best treatment option.

\section{Abbreviations \\ ARA: Accessory renal artery; PKB: Percutaneous kidney biopsy; DSA: Digital subtraction angiography; CTA: Computed tomography angiography.}

\section{Acknowledgements}

Not applicable.

\section{Authors' contributions}

$\mathrm{LD}$ and $\mathrm{ZH}$ contributed to manuscript drafting and reviewed the literature. YM collected and collated clinical data. JH and YN completed the renal pathology report. CG lead the interventional surgery. ZXM supervised the entire project and help to write the manuscript. All author approve the final version of the manuscript.

\section{Funding}

This work was supported by Binzhou Science and Technology Development Project (NO. 2011zc0913) and Shandong Medicine and Health Science Technology Development Project (NO. 2017WS689).

\section{Availability of data and materials}

The data were available upon appropriate requests.

\section{Ethics approval and consent to participate}

The subjects (or their parents or guardians) have given their written informed consent to publish their case (including publication of images).

\section{Consent to publish}

Written informed consent for publication of their clinical details and/or clinical images was obtained from the patient.

\section{Competing interests}

The authors declare that they have no competing interests.

\begin{abstract}
Author details
${ }^{1}$ Department of Nephrology, Binzhou Medical University Hospital, No. 661 Huanghe Second Road, Binzhou 256603, Shangdong, P.R. China. ${ }^{2}$ Department of Pathology, Binzhou Medical University Hospital, No. 661 Huanghe Second Road, Binzhou 256603, Shandong, P.R. China. ${ }^{3}$ Department of Vascular Intervention, Binzhou Medical University Hospital, No. 661 Huanghe Second Road, Binzhou 256603, Shandong, P.R. China.
\end{abstract}

Received: 26 May 2020 Accepted: 20 October 2020

Published online: 29 October 2020

\section{References}

1. Kuo PC, Bartlett ST, Schweitzer EJ, Johnson LB, Lim JW, Dafoe DC. A technique for management of multiple renal arteries after laparoscopic donor nephrectomy. Transplantation. 1997;64(5):779-80.

2. van Roijen JH, Kirkels WJ, Zietse R, Roodnat Jl, Weimar W, ljzermans JN Long-term graft survival after urological complications of 695 kidney transplantations. J Urol. 2001;165(6 Pt 1):1884-7.

3. Markowitz G. Glomerular disease: Updated Oxford Classification of IgA nephropathy: a new MEST-C score. Nat Rev Nephrol. 2017;13(7):385-6.

4. Korbet SM, Volpini KC, Whittier WL. Percutaneous renal biopsy of native kidneys: a single-center experience of 1,055 biopsies. Am J Nephrol. 2014;39(2):153-62.

5. Prasad N, Kumar S, Manjunath R, Bhadauria D, Kaul A, Sharma RK, Gupta A, Lal H, Jain M, Agrawal V. Real-time ultrasound-guided percutaneous renal biopsy with needle guide by nephrologists decreases post-biopsy complications. Clin Kidney J. 2015;8(2):151-6.

6. Peters B, Andersson Y, Stegmayr B, Molne J, Jensen G, Dahlberg P, HolmGunnarsson I, Ekberg J, Bjurstrom K, Haux SB, et al. A study of clinical complications and risk factors in 1,001 native and transplant kidney biopsies in Sweden. Acta Radiol. 2014;55(7):890-6.

7. Waldo B, Korbet SM, Freimanis MG, Lewis EJ. The value of post-biopsy ultrasound in predicting complications after percutaneous renal biopsy of native kidneys. Nephrol Dial Transplant. 2009;24(8):2433-9.

8. Harada K, Tsukahara J, Kasahara Y, Sumida K, Yamaguchi Y, Yasui H, Akai Y. Resolution of proteinuria after transarterial embolization of aberrant renal artery in a patient with focal segmental glomerulosclerosis. CEN Case Rep. 2015;4(2):145-50.

9. Zhang Q, Ji Y, He T, Wang J. Ultrasound-guided percutaneous renal biopsy-induced accessory renal artery bleeding in an amyloidosis patient. Diagn Pathol. 2012;7:176.

10. Tao XF, Zhu JQ, Wu YW, Tang GY, Shi YZ, Zhang L, Lin Y, Wang ZQ. Dualenergy computed tomography angiography for evaluating the renal vascular variants. Chin Med J (Engl). 2013;126(4):650-4.

11. Merklin RJ, Michels NA. The variant renal and suprarenal blood supply with data on the inferior phrenic, ureteral and gonadal arteries: a statistical analysis based on 185 dissections and review of the literature. J Int Coll Surg. 1958;29(1 Pt 1):41-76.

12. van Baalen JM, van Bockel HJ. Thoracic origin of right renal artery. J Vasc Surg. 1994;19(4):762-3.

13. Chan PL, Tan FHS. Renin dependent hypertension caused by accessory renal arteries. Clin Hypertens. 2018;24:15.

14. Krzemien G, Soltyski J, Szmigielska A, Warchol S, Dudek-Warchol T, Jakimow-Kostrzewa A. Dodatkowa tetnica nerkowa przyczyna skrajnego wodonercza u 5-letniego chlopca. Pol Merkur Lekarski. 2018;44(262):201-4.

15. Aytac SK, Yigit H, Sancak T, Ozcan H. Correlation between the diameter of the main renal artery and the presence of an accessory renal artery: sonographic and angiographic evaluation. J Ultrasound Med. 2003;22(5):433-9.

16. Chai JW, Lee W, Yin YH, Jae HJ, Chung JW, Kim HH, Park JH. CT angiography for living kidney donors: accuracy, cause of misinterpretation and prevalence of variation. Korean J Radiol. 2008;9(4):333-9.

17. Ngoh CLY, Wee BBK, Wong WK. Lumbar artery bleed as a complication of percutaneous renal biopsy and a proposed workflow for massive bleeding. Case Rep Nephrol Dial. 2018;8(3):268-76.

18. Dinkel HP, Danuser H, Triller J. Blunt renal trauma: minimally invasive management with microcatheter embolization experience in nine patients. Radiology. 2002;223(3):723-30.

\section{Publisher's Note}

Springer Nature remains neutral with regard to jurisdictional claims in published maps and institutional affiliations. 